\title{
ALLOWANCES FOR BREACHING FIDUCIARIES TO ENSURE THAT THE PRINCIPAL WHO SEEKS EQUITY MUST DO EQUITY: WHY NOT QUANTUM MERUIT?
}

\author{
ANJA KANTIC*
}

This article considers the potential application of unjust enrichment on a quantum meruit basis to the assessment of allowances for breaching fiduciaries. It briefly outlines the jurisprudential basis for these allowances and then explores the role of unjust enrichment in awarding relief to a breaching party to a contract. Although such a party has breached the contract, quantum meruit operates to ensure that they are fairly compensated for work done or effort expended. The article argues that there are substantial similarities between the position of the party who has breached a contract and that of the breaching fiduciary. It is therefore useful to explain the potential application of quantum meruit to the assessment of allowances for breaching fiduciaries to ensure that the principal who seeks equity must do equity.

\section{CONTENTS}

I

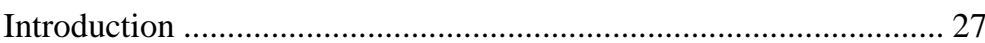

II The Jurisprudential Basis For Allowances ................................... 27

A Why Allow Allowances?............................................... 28

III Breach of Contract: The Breaching Party's Entitlement to Claim..... 29

A Measuring Unjust Enrichment ........................................... 31

IV Quantum Meruit for a Breaching Fiduciary .................................. 34

A Theoretical Implications ................................................... 34

B Application of Quantum Meruit to Allowances ................... 38

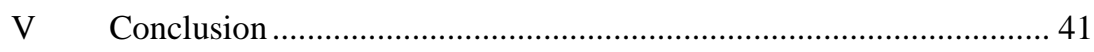

LLB (Hons) (University of South Australia); Lecturer at the University of South Australia Law School. I thank Professor Charles Rickett and Jane Knowler for their constructive feedback on earlier drafts. 


\section{INTRODUCTION}

It has long been established that fiduciaries may be entitled to an allowance for work, skill or effort expended in pursuit of endeavours that amount to breaches of their fiduciary duties. ${ }^{1}$ This article argues that the preferred approach for courts to take in making allowances is to rely on the principle of unjust enrichment set out in Warman International v Dwyer ('Warman') ${ }^{2}$ rather than to focus on the dishonest conduct of the breaching fiduciary. Its aim is to draw from the existing unjust enrichment law dealing with contractual breaches and explain how this law (in particular restitutionary quantum meruit) may apply to allowances for breaching fiduciaries. This requires an inquiry into cases of breach of contract where the breaching party, despite clearly being the party 'in the wrong', is able to claim remuneration on a quantum meruit basis for work done, services performed or other forms of time, effort or money expended.

The 'unjust' factor justifying the award of restitutionary quantum meruit is common both to allowances for breaching fiduciaries and to payments (essentially a form of 'allowance') awarded to breaching contract parties. If the aim is to recognise that a party is entitled to some reward for effort in order to avoid unjust enrichment of the 'innocent' non-breaching contracting party or the wronged principal in a fiduciary relationship, then it is vital to examine whether quantum meruit can apply to cases of allowances for breaching fiduciaries. This approach will provide coherence and stability for courts when making allowance assessments.

\section{THE JURISPRUDENTIAL BASIS FoR ALlOWANCES}

First, a brief examination of the rationale that underpins the award of allowances for breaching fiduciaries is required. The honesty or otherwise of the breaching fiduciary may be considered by a court in deciding whether to make an allowance, but it is not determinative of whether an allowance will be made. ${ }^{3}$ Rather, the question is: why are allowances made to breaching fiduciaries at all? Unravelling the logic behind the granting of allowances

See generally Boardman v Phipps [1967] 2 AC 46.

(1995) 182 CLR 544.

Chirnside v Fay [2007] 1 NZLR 433 (SCNZ) [43] (Elias CJ). 
provides greater insight into how unjust enrichment can be used to assist a court to make fair and consistent calculations about these allowances.

\section{A Why Allow Allowances?}

There is no doubt that a fiduciary is required to act with the utmost loyalty to and regard for the principal's interest. ${ }^{4}$ A breach of fiduciary duty is regarded as an ultimate betrayal in the eyes of the law, which raises the question of why courts make allowances for breaching fiduciaries at all. The purpose of the law in this area is to protect principals from a breach of duty, rather than to fashion mechanisms to reward errant fiduciaries. ${ }^{5}$ Considering the merits of these arguments requires an assessment of the foundational principles behind granting allowances. If a penal perspective is taken, then an allowance should not be permitted at all because it would 'encourage' fiduciaries to breach their duties. ${ }^{6}$ However, it is highly questionable whether deterrence plays any role in assessing allowances. The threat of potential fiduciary liability and other sanctions do not dissuade the breaching fiduciary (whether acting for honest entrepreneurial reasons or otherwise), and ' $[\mathrm{t}]$ here is no empirical evidence whatever to suggest that potential loss of profit has any effect upon them'. ${ }^{7}$ If the fallacy that punishment is a deterrent is disposed of, it is clear that some type of allowance must be made. '[T]he skill expended by the innocent or wicked fiduciary is the same ${ }^{8}$ and results in a benefit to the principal.

Equity's usual response to a breach of fiduciary duty is to consider the profits made by the fiduciary, rather than the loss of the principal, and to require the fiduciary to account for those profits. ${ }^{9}$ Disgorgement of profits is the appropriate response of the law in this situation, and as such, the justification for making an allowance must be consistent with the idea of disgorgement. Aitken suggests that the court, 'should assess, as best it can, the actual capital profit derived from the activity jointly entered by the fiduciary, and then with

4 See generally Chan v Zacharia (1984) 154 CLR 178, Breen v Williams (1996) 186 CLR 71, Bristol and West Building Society v Mothew [1998] Ch 1.

5 Green and Clara Pty Ltd v Bestobell Industries Pty Ltd (No 2) [1984] WAR 1, 38 (Brinsden $\mathrm{J})$ : 'this branch of the law is prophylactic, not restitutionary'.

6 Lee Aitken, 'Reconciling "Irreconcilable Principles" - A Revisionist View of the Defaulting Fiduciary's “Generous Equitable Allowance”" (1993) 5 Bond Law Review 49, 51.

7 Ibid 60.

8 Ibid.

$9 \quad$ Regal (Hastings) Ltd v Gulliver [1967] 2 AC 134, 156 (Lord Wright). 
the assistance of expert evidence make a proper division of the gain'. ${ }^{10}$ The disgorgement of profits prevents the fiduciary benefiting from their wrongdoing - essentially from being enriched through their own misconduct. However, the law has long recognised that those who seek equity must do equity. ${ }^{11}$ In the context of making allowances, Mason, Carter and Tolhurst refer to this as 'counter-restitution', ${ }^{12}$ meaning that an allowance must be made because the principal will be unjustifiably enriched if they retain all of the profits without any acknowledgement of the work, skill and effort expended by the fiduciary. To prevent such unjustifiable enrichment, some means must be devised of fairly attributing a portion of the total profit made to the work done by the fiduciary. An example is provided by the common law when courts assess the value of the work done by a breaching party to a contract.

\section{BREACH OF CONTRACT: THE BREACHING PARTY's ENTITLEMENT TO}

\section{CLAIM}

A party who has breached their contractual obligations may nevertheless be entitled to some remuneration based on money paid or the value of goods or services provided. ${ }^{13}$ The unjust enrichment claim operates independently of the contractual relationship between the parties, ${ }^{14}$ just as a breaching fiduciary's claim for an allowance operates independently of the fiduciary relationship between the parties. Although both breaching parties have failed to uphold their strict duty to perform particular obligations, the claim for an allowance is an issue separate from this breach, and consequently the contracting party in breach and the breaching fiduciary are in a similar position.

The key issue when dealing with restitution for a non-monetary benefit is establishing the requisite unjust factor 'which makes the enrichment unjust, and restitution necessary'. ${ }^{15}$ Free acceptance is the most applicable 'unjust factor' when attempting to draw a connection between the claim by the

10 Aitken, above n 6, 60.

11 Keith Mason, J W Carter and G J Tolhurst, Mason and Carter's Restitution Law in Australia (Butterworths, $2^{\text {nd }}$ ed, 2008) 705 [1735].

12 Ibid.

13 See generally Steele v Tardiani (1946) 72 CLR 386.

14 Mason, Carter and Tolhurst, above n 11, 466 [1162].

15 Rohan Havelock, 'A Taxonomic Approach to Quantum Meruit' (2016) 132 Law Quarterly Review 470, 489. 
breaching party to contract and the claim by the breaching fiduciary. ${ }^{16}$ This is because we are not dealing with a void, voidable, anticipated or frustrated contract, or a situation where there has been a total or partial failure of basis. ${ }^{17}$ Instead, there was a valid contract governing the relationship between the parties, but it has been terminated due to the breach of one of the parties. The 'innocent' party may terminate the contract and claim damages, but the breaching party will be able to claim on a quantum meruit basis if the other party has 'accepted' the work done.

Justice Dixon commented that 'acceptance' extends to 'taking the benefit of work'; ${ }^{18}$ it is necessary for the defendant to have some kind of practical choice. ${ }^{19}$ This presents difficulties in situations where the defendant does not have any notice or awareness of the benefit until it has been transferred, such as where the principal has no awareness of the benefit obtained by the fiduciary's breach until the breach has been discovered. However, this is not fatal to the claim. For example, the plaintiff (who breached the contract) in Steele $v$ Tardiani successfully claimed remuneration for the value of loose building materials used by the defendant. ${ }^{20}$ Although the defendant did not have a say in whether these materials were left at the building site, the defendant could have chosen not to use them for his benefit. ${ }^{21}$

Mason, Carter and Tolhurst remark that '[a]cceptance may be found after the receipt of performance, in the failure to return the benefit'. ${ }^{22}$ Weinrib also argues that acceptance can be imputed in the particular circumstances through failure to prevent a non-gratuitous transfer, failure to reverse a transfer where this is reasonably possible, or where the benefit transferred forwards the

16 The focus of this article is on actions by parties who have performed work and also breached the contract because this applies most fittingly to instances of breach of fiduciary duty. Other instances of unjust enrichment require special consideration. For example, the basis for an action for money had and received is recovery of money paid under an ineffective contract; however, this requires consideration of the factors which are unique to that claim (which is beyond the scope of this article).

17 Havelock, above n 15, 487-492.

$18 \quad$ Steele v Tardiani (1946) 72 CLR 386.

19 For criticisms of free acceptance, see generally Andrew Burrows, 'Free Acceptance and the Law of Restitution' (1988) 104 Law Quarterly Review 576; Ross Grantham and Charles Rickett, Enrichment and Restitution in New Zealand (Hart Publishing, 2000).

$20 \quad$ Steele v Tardiani (1946) 72 CLR 386.

21 Ibid 392 (Latham CJ).

22 Mason, Carter and Tolhurst, above n 11, 467 [1164]. 
defendant's purpose. ${ }^{23} \mathrm{~A}$ transfer of goods, services or money will almost always benefit the defendant's interests, so it is evident that the free acceptance principle potentially has wide application based on Weinrib's explanation. ${ }^{24}$ The fact that the defendant does not have a 'choice' before the conferral of the benefit does not change the outcome. Any party who retains the benefit of work, goods, services or money after realising that they have been conferred can be said to impliedly accept the benefit, thereby satisfying the 'unjust' factor in the unjust enrichment claim. The claimant can then seek reasonable remuneration for the benefit of the work, goods, services or money provided on a quantum meruit basis.

It is essentially irrelevant that the claimant party has breached the contract; the non-breaching party is entitled to terminate the contract if the breach is sufficiently severe, ${ }^{25}$ and to claim damages if they establish loss. The 'innocent' party's claims do not preclude the breaching party's claims on a quantum meruit basis. The 'innocent' party would be unjustly enriched if they retained the entire benefit conferred without paying the breaching party for the value of services they had performed/given. ${ }^{26}$ Therefore, allowing a quantum meruit claim can be seen as implementing 'counter-restitution' $;{ }^{27}$ the same term Mason, Carter and Tolhurst apply to justify allowances for breaching fiduciaries.

\section{A Measuring Unjust Enrichment}

Before assessing the potential application of quantum meruit principles to allowances for breaching fiduciaries, it is useful briefly to consider the foundational basis of unjust enrichment claims. Barker suggests that unjust enrichment claims can be explained by the idea of legal (as opposed to moral)

23 Kit Barker, 'The Nature of Responsibility for Gain: Gain, Harm, and Keeping the Lid on Pandora's Box' in Robert Chambers, Charles Mitchell and James Penner, Philosophical Foundations of the Law of Unjust Enrichment (Oxford University Press, 2009) 146 citing Ernest Weinrib, 'The Normative Structure of Unjust Enrichment' in Charles Rickett and Ross Grantham (eds), Structure and Justification in Private Law (Oxford University Press, 2008) 21.

24 Cf Matthew Doyle, 'Corrective Justice and Unjust Enrichment' 62 University of Toronto Law Journal 229, 246 criticising Weinrib's approach: '[r] espect for the defendant's status as a selfdetermining agent consequently demands that he be given a meaningful opportunity to exercise a choice as to whether or not to accept the enrichment'.

25 See generally Koompahtoo Local Aboriginal Land Council v Sanpine Pty Ltd (2007) 233 CLR 115.

$26 \quad$ See, eg, Steele v Tardiani (1946) 72 CLR 386.

27 Mason, Carter and Tolhurst, above n 11, 705 [1735]. 
responsibility for gain. ${ }^{28}$ It is particularly useful to focus on the relationship between gain and harm when assessing unjust enrichment because the aim of the law is to prevent the unjust conferral of a benefit from one party to the other. Barker comments that the doctrine is deliberately termed 'unjust enrichment' as opposed to 'unjust loss'; ${ }^{29}$ the focus is on the enrichment of the defendant rather than the loss of the plaintiff. ${ }^{30}$ This is unique given that the immediate response of the law in most claims ${ }^{31}$ is to require 'provable factual loss ${ }^{32}$ by the claiming party.

Unjust enrichment is not concerned with harm in isolation and does not require assessment of loss caused to one party (like a claim for damages). ${ }^{33}$ It is focused on the unjust retention of a benefit by one party at the expense of the other. ${ }^{34}$ This 'expense' could arguably be construed as a form of harm, but it is not sufficient on its own to ground a claim in unjust enrichment - loss is only relevant insofar as it is the inverse of the benefit retained by the defendant. 'A defendant's "unjust" gain must, intrinsically, be one that is made at "a plaintiff's expense" in the sense of being related to a setback of entitlement, otherwise no injustice exists between the two'. ${ }^{35}$ The 'entitlement' of the plaintiff is the right to fair remuneration for work done. ${ }^{36}$ Both parties to a contract have this right, and unjust enrichment may operate in situations where

28 Barker, above n 23, 147.

29 Ibid 153

30 Cf Steve Hedley, What Is 'Unjust Enrichment' For? (Review: Charlie Webb, 'Reason and Restitution: A Theory of Unjust Enrichment' (University College Cork, 2016) 7, citing Charlie Webb, Reason and Restitution: A Theory of Unjust Enrichment (Oxford University Press, 2016) 178 .

31 Tort, breach of contract etc. See Sarah Worthington, 'Four Questions on Fiduciaries' (2016) 2 Canadian Journal of Comparative and Contemporary Law 723, 734.

32 Barker, above n 23, 174.

33 Cf Barker, above n 23, ch 6 for different models of causal responsibility, some of which relate to harm and others which do not. This also contains a discussion of moral responsibility and prevention of harm which is beyond the scope of this article.

34 See Graham Virgo, 'All the World's a Stage: The Seven Ages of Unjust Enrichment' (Research Paper No. 51, University of Cambridge Faculty of Law, 2016) 22 for a discussion of the focus on 'unconscionable retention' rather than 'unjust enrichment'. See also 25: 'restitutionary liability is founded on unconscionable retention, but this is not sufficient in its own right to explain when liability will be imposed. The doctrine of unjust enrichment does that work'.

35 Barker, above n 23, 172 (emphasis in original).

36 Or more generally, the agreed contractual remuneration for performance. 
one party does work that benefits the other but does not receive any recognition for this work.

Barker explains unjust enrichment in a corrective justice paradigm, as there must be some kind of disruption in the equality of the bargain and balance of the relationship between the two parties. ${ }^{37}$ This occurs where one party's work is not acknowledged; and if there is no contract governing the remuneration for this work, then the plaintiff will need to establish a claim in unjust enrichment. Doyle refers to this need to achieve balance as 'the norm to which the interaction between the parties ought to conform' ${ }^{38}$ It is necessary for the retention of the benefit to be unjust in order to attract legal consequences because the law will not interfere with the standard apportionment of loss and gain between two self-interested contracting parties. ${ }^{39}$ Barker also refers to the two-sided assessment of fiduciary relationships, in the sense that the focus is not necessarily on a loss to the principal; rather, the law will interfere as soon as there is an unlawful gain made by the fiduciary. ${ }^{40} \mathrm{I}$ will explore the utility of a quantum meruit approach in the context of allowances for breaching fiduciaries further in Part IV.

Barker's question of legal responsibility in the context of quantum meruit can therefore be framed as: who should bear legal responsibility for recognising the value of work done? This question of responsibility is distinct from contractual wrongdoing, and entitles the breaching party to claim on a quantum meruit basis because it is the 'innocent' party who bears the legal responsibility for recognising the value of the breaching party's work. It is necessary to maintain this balance in order to avoid over-compensation of the 'innocent' party and to acknowledge that the quantum meruit claim is separate in substance from the contractual claim. ${ }^{41}$ It is evident that both judicial and academic commentators recognise the use of unjust enrichment principles to remunerate a breaching party for work which they have done. ${ }^{42}$ Quantum

37 Barker, above n 23, 168.

38 Doyle, above n 24, 235-6.

39 Barker, above n 23, 157.

40 Ibid 161. See generally Regal (Hastings) Ltd v Gulliver [1967] 2 AC 134, Attorney-General $v$ Blake [2001] AC 268.

41 The same can be said of fiduciaries: the question of allowance is distinct from the fiduciary's wrongdoing.

42 See, eg, Steele v Tardiani (1946) 72 CLR 386; Angas O'Brien, 'The Relationship Between the Laws of Unjust Enrichment and Contract: Unpacking Lumbers v Cook' (2011) 32 Adelaide Law Review 83; Stephen Waddams, 'Contract and Unjust Enrichment: Competing Categories, 
meruit is calculated based on the value of services or goods they have conferred, namely, where their effort provides some kind of benefit to the other party. So, the question is whether this also applies when granting allowances to breaching fiduciaries?

\section{QUANTUM MERUIT FOR A BREACHING FIDUCIARY}

Principles of unjust enrichment have been used in Australia as a tool for judicial assessment of allowances for breaching fiduciaries. ${ }^{43}$ Some authors have commented that 'corrective justice reverses wrongful gains' ${ }^{44}$ In order to achieve this reversal, it is worth considering the application of quantum meruit as the remedial measure ${ }^{45}$ under the unjust enrichment approach to granting allowances. ${ }^{46}$ When making an allowance for a breaching fiduciary based on work, skill or effort expended, ${ }^{47}$ the assessment is practically similar to the approach taken by courts when assessing work done on a quantum meruit basis. Given that the claimant's action in both instances can be viewed as one in unjust enrichment (with the fiduciary arguing that it is unjust for the principal to retain the benefit of work done without acknowledging the fiduciary's effort), it is possible that quantum meruit could provide the measure of reasonable remuneration.

\section{A Theoretical Implications}

The idea of likening a breach of fiduciary duty to a breach of contract is controversial. It has been criticised as allowing the breaching fiduciary to effectively claim 'the very recompense he might have achieved by agreement if he had faithfully discharged his fiduciary responsibilities' ${ }^{48}$ This advances the view that a breaching fiduciary should not receive any allowance for simply

or Complementary Concepts?' in Charles Rickett and Ross Grantham (eds), Structure and Justification in Private Law: Essays for Peter Birks (Hart Publishing, 2008) ch 9.

43 Warman International v Dwyer (1995) 182 CLR 544.

44 See Bronwyn Arnold, 'What Shall We Do with the Dishonest Fiduciary? The Unpredictability of Allowances for Work and Skill' (2016) 2 University of South Australia Law Review 1, 17.

45 Havelock, above n 15, 494.

46 Warman International v Dwyer (1995) 182 CLR 544.

47 As opposed to the misappropriation of property: see Fraser Edmiston Pty Ltd $v$ AGT (Qld) Pty Ltd [1988] 2 Qd R 1, cited in Aitken, above n 6, 58.

48 Chirnside v Fay [2007] 1 NZLR 433 (SCNZ) [47] (Elias CJ). This decision warrants its own detailed analysis and will be explored as a practical example in a planned sequel to this article. 
performing the tasks they had agreed to undertake. Rewarding the fiduciary for work which they were in any event obliged to perform would effectively condone the breach of fiduciary duty. 'To grant him an allowance simply for fulfilling the role expected of him within the scope of the joint venture is inconsistent with the no-profit rule' ${ }^{49}$ It is well established that fiduciaries are held to a much higher standard than self-interested contracting parties and as a result owe unique duties of loyalty. ${ }^{50}$ From this perspective, the breach of contract analogy does not neatly align with a breach of fiduciary duty. However, if we take the view that granting allowances undermines the fiduciary's role and fails to provide a deterrent for breach, we are back at square one; and as Part II explains, this deterrent theory is not persuasive. On the other hand, if we concede that allowances will be made and that unjust enrichment is the appropriate mechanism for justifying them, it is worth considering the potential application of quantum meruit as an objectively assessable (and fair) means of calculating allowances. This may in essence result in the fiduciary being compensated for work done and only having to part with the net profit made.

A remedy that requires the fiduciary only to disgorge profits is not unheard of in equity because its aim is not to punish the fiduciary. ${ }^{51}$ It is to ensure that profits resulting from the breach of fiduciary duty are accounted for, while at the same time ensuring that the principal (the 'innocent' party) is not unfairly rewarded. The Supreme Court of New Zealand has described the exercise that courts undertake in this scenario:

It [is] not the purpose of the surrogate accounting exercise upon which the Court [is] engaged to apply a sanction or punishment for the breach of duty. The true purpose of the exercise [is] to fix compensation or damages on the basis of disgorgement of profits properly analysed. ${ }^{52}$

When distinguishing fiduciary duties from contractual duties, it is worth noting that the former attract another distinct feature which does not apply to the latter, but which strengthens the argument for a just and impartial allowance being made for the breaching fiduciary; the principal who seeks equity's

49 Ibid [48] (Elias CJ).

50 Stephen Smith, 'The Deed, Not the Motive: Fiduciary Law Without Loyalty' in Paul Miller and Andrew Gold (eds), Contract, Status and Fiduciary Law (Oxford University Press, 2016 forthcoming) ch 9 .

51 See generally Harris v Digital Pulse Pty Ltd (2003) 56 NSWLR 298, 422 [470] (Heydon JA), Vadasz v Pioneer Concrete (SA) Pty Ltd (1995) 184 CLR 102, 114 citing Spence v Crawford [1939] 3 All ER 271, 289 (Lord Wright).

52 Chirnside v Fay [2007] 1 NZLR 433 (SCNZ) [142] (Blanchard and Tipping JJ). 
assistance in claiming an account of profits must do equity. The High Court has commented that 'the liability of the fiduciary should not be transformed into a vehicle for the unjust enrichment of the plaintiff' ${ }^{53}$ It is necessary to achieve some balance between upholding the 'no-profit' rule ${ }^{54}$ on the one hand and recognising the efforts of the fiduciary on the other. Burrows considers several means of achieving this balance:

One approach therefore is to fix the quantum at the initial gain received by the wrongdoer. Another is to allow the courts to control remoteness of gain through the discretionary allowance for time and skill with the courts taking into account a variety of factors, such as the degree of skill and effort expended and whether the wrongdoer was acting honestly or not. ${ }^{55}$

The latter approach has particular value in the context of quantum meruit. It is useful for those cases of breach of fiduciary duty that 'bear a significantly closer resemblance to a breach of contract than to anything fraudulent'; 56 namely, situations where the breaching fiduciary has misused their position to undertake a profitable endeavour. ${ }^{57}$ Just as courts make an educated estimate in other situations (such as an award of quantum meruit following breach of contract) the courts can objectively assess the value of the work done (with expert evidence if necessary) by the breaching fiduciary to grant a fair allowance in the circumstances.

A key issue raised by the use of quantum meruit in breach of fiduciary duty cases is how to satisfy the so-called 'unjust' factor. It has long been established that free acceptance of work done enlivens the 'injustice' in an unjust enrichment claim, ${ }^{58}$ but how does this idea of acceptance tie in with a breach of fiduciary duty where the principal is (in most instances) completely unaware of the fiduciary's breach until it is too late for the principal to have an effective choice to accept? From a practical perspective, the principal does not have the

53 Warman International v Dwyer (1995) 182 CLR 544, 561 [33] (Mason CJ, Brennan, Deane, Dawson and Gaudron JJ).

54 Cf Smith, above n 50, ch 9.

55 Andrew Burrows, The Law of Restitution (Oxford University Press, $3^{\text {rd }}$ edition, 2011) 688. See also Ross Grantham and Charles Rickett, Enrichment and Restitution in New Zealand (Hart Publishing, 2000) 487.

56 Chirnside v Fay [2007] 1 NZLR 433 (SCNZ) [143] (Blanchard and Tipping JJ).

57 As opposed to situations of misappropriated fiduciary property which raise more complex issues such as constructive trusts: see eg Guinness plc v Saunders [1990] 2 AC 663.

58 See, eg, Lumbers $v$ W Cook Builders (in liquidation) (2008) 232 CLR 635, 656 [53] (Gleeson CJ); Charles Mitchell, Paul Mitchell and Stephen Watterson (eds), Goff \& Jones: The Law of Unjust Enrichment (Sweet \& Maxwell, 8 ${ }^{\text {th }}$ ed, 2011) 453. 
opportunity to accept or reject the work done because they are unaware of the breach occurring. ${ }^{59}$ If the principal is aware and does accept the work done prior to the breach of fiduciary duty itself, then there is no issue of allowance because the fiduciary has the informed consent of the principal to make the profit. The difficulty arises in situations where there is no opportunity to accept or reject available to the principal.

It is useful, however, to remember Weinrib's definition of acceptance in the context of unjust enrichment discussed in Part III; he maintains that the retention of a benefit after it has been transferred can amount to acceptance. ${ }^{60}$ Furthermore, the principal may be better off 'impliedly' accepting the fiduciary's breach and claiming the associated profits as well as the benefit of the work done, while also granting the fiduciary an allowance for their efforts. Even in situations where substantial allowances are made for work done by a breaching fiduciary, the principal may be left with valuable improvement to their property or the benefit of an asset which they would not have otherwise had. In some instances, principals have commented that they would have allowed the fiduciary a greater share of the profits for the work that they had done in breach of duty. ${ }^{61}$ The making of an allowance using quantum meruit simplifies this task for courts; and if they are required to make an allowance, then it is useful to rely on an established system of calculation to provide some guidance and consistency.

The fiduciary's claim for an allowance could operate like an unjust enrichment claim, whereby the principal would be unjustly enriched if they retained the benefit of the entire profit without recognising the fiduciary's work, skill and effort to some extent (with this work, skill and effort to be calculated on a quantum meruit basis). ${ }^{62}$ Alternatively, quantum meruit could be used as a 'defence' by the fiduciary to justify the granting of an allowance. This is similar to the manner in which the law currently operates, whereby the fiduciary does not have an automatic right to an allowance, but rather must

59 Mason, Carter and Tolhurst, above n 11, 70 [174].

60 Barker, above n 23, 146 citing Ernest Weinrib, 'The Normative Structure of Unjust Enrichment', in Charles Rickett and Ross Grantham (eds), Structure and Justification in Private Law (Hart Publishing, 2008) 21.

61 Fay v Chirnside and Rattray Properties Ltd HC DUN CIV-2001-412-00013 (15 August 2003) [77].

62 Phipps v Boardman [1964] 1 WLR 993, 1019: 'it would be inequitable now for the beneficiaries to step in and take the profit without paying for the skill and labour which produced it'. Statement approved on appeal in Boardman v Phipps [1967] 2 AC 46, 104. 
show why they deserve one. ${ }^{63}$ The allowance can be seen to operate as a means of controlling remoteness of gain. ${ }^{64}$ The final Section of this article will consider the practical consequences of this suggestion. ${ }^{65}$

\section{B Application of Quantum Meruit to Allowances}

The clearest way to highlight the utility of the quantum meruit approach is to refer to a practical example. The case of Chen $v$ Lym International Pty Ltd ('Lym' ${ }^{66}$ was considered in Arnold's primary article and can usefully be revisited here.$^{67}$ The facts and history of the case can be briefly summarised as involving a project manager (Chen) who sold himself a property and completed a profitable property development in breach of fiduciary duty owed to a company (Lym). The first step always taken by courts is to determine whether it is appropriate to award an allowance. ${ }^{68}$ The Court of Appeal in this instance determined that an allowance was necessary, 'because otherwise Lym would receive the property at a vastly increased value without the financial drawback of having to develop the property itself' ${ }^{69}$ After deciding that it is in fact appropriate to make an allowance, the next question is to determine how this allowance should be made.

The quantum meruit approach could be used in a case like Lym and the breaching fiduciary could be remunerated as a project manager based on the value of services and the average hourly rate of a project manager in that position. In this case, Chen was still required to disgorge the profit, but received a substantial allowance for his skill and effort in developing the property. Lym had no practical choice to accept or reject the services in question prior to the breach, but the company had undoubtedly benefited from

63 Matthew Harding, 'Justifying Fiduciary Allowances' in Andrew Robertson and Hang Wu Tang (eds) The Goals of Private Law (Hart Publishing, 2009) 341, 352.

64 Burrows, above n 55, 688. See also Grantham and Rickett, above n 55, 487.

65 It is important to note that this will be a brief overview.

66 [2009] NSWCA 326.

67 See Arnold, above n 44, 11-2.

68 The trial judge in this case refused to grant an allowance but this was overturned on appeal. See Chen v Lym International Pty Ltd [2009] NSWCA 326 [330] (Young JA).

69 Arnold, above n 44, 12. See also Chen v Lym International Pty Ltd [2009] NSWCA 326 [335] (Young JA). 
the work done by Chen. ${ }^{70}$ Even if Lym had an opportunity to reject the services or somehow rescind the transaction, it would be foolish to do so when the endeavour proved to be so profitable. The logical thing for the principal to do in these circumstances is to impliedly/retrospectively accept the work done and require disgorgement of profits gained by the breaching fiduciary because this profit in essence belongs to the principal. If appropriate, the court may make an allowance to reflect the value of the work, skill and effort by the fiduciary. The issue is how the court should go about making this allowance.

In many cases, the situation will be far more complex than a basic calculation of hours of work done. ${ }^{71}$ Such an assessment does not consider the risks associated with the endeavour, nor the industry knowledge and skills unique to that particular individual. However, the truth is that allowances must inevitably be made and there will never be a perfect formula to apply. Judges have discretion in their approach to calculating allowances, and this discretion could extend to using quantum meruit as the "appropriate remedial measure'72 to objectively assess the value of work done by a breaching fiduciary.

To return to Lym as an example, Chen could claim for money spent in completing the lucrative property development while still disgorging the profit (so that this would be the profit less the amount of allowance). Applying Aitken's methodology, ${ }^{73}$ the court should assess the actual capital profit derived from the activity, and then use expert evidence to make a proper division of the gain. ${ }^{74}$ This 'proper division' could be made by assessing the total value of the property development, and then calculating the amount of time and effort expended by the breaching fiduciary. The monetary value of this time and effort could be calculated on an hourly basis while also taking into account the value of the fiduciary's individual skill and business expertise. The task of assessing the allowance is similar to the task of assessing the value of the work done by the breaching party to a contract, in that quantum meruit can be used in both situations to assess the quantum of the remedy.

\footnotetext{
70 Barker, above n 23, 146 citing Ernest Weinrib, 'The Normative Structure of Unjust Enrichment' in Charles Rickett and Ross Grantham (eds), Structure and Justification in Private Law (Oxford University Press, 2008) 25.

71 Chirnside v Fay [2007] 1 NZLR 433 (SCNZ) [110] (Blanchard and Tipping JJ).

72 Havelock, above n 15, 494.

73 Aitken, above n 6, 60.

74 Chirnside v Fay [2007] 1 NZLR 433 (SCNZ) [110] (Blanchard and Tipping JJ).
} 
In some instances, this process will result in a substantial allowance for the breaching fiduciary. ${ }^{75}$ The outcome may even be a situation where the breaching fiduciary is entitled to claim the value of the entire profit as an allowance. ${ }^{76}$ However, such is the nature of the equitable remedy - it is not designed to punish the breaching fiduciary or to single out dishonest fiduciaries. It is designed to achieve fairness and avoid over-compensation of the 'innocent' party. Dishonesty is one factor to be considered when deciding whether to grant an allowance, and if so, how much that allowance should be. However, Australian courts have indicated that dishonesty is by no means determinative, ${ }^{77}$ and that the underlying consideration is that 'the liability of the fiduciary should not be transformed into a vehicle for the unjust enrichment of the plaintiff' ${ }^{78}$ This means that it is necessary to make an allowance which fairly reflects the skill and effort of the fiduciary. ${ }^{79}$

The use of quantum meruit to calculate an allowance based on reasonable remuneration of the fiduciary requires deeper analysis, but its utility is evident at first glance. The quantum meruit approach is at the very least useful for instances of fiduciary breach that are inherently 'contractually based' 80 and involve a fiduciary embarking on a profitable endeavour without the consent of the principal. Although the fiduciary has committed a wrong and must account for those profits, it is also necessary for the principal to recognise the value of the skill and effort expended by the fiduciary in order to achieve counter-restitution and ensure that the principal who is seeking the assistance of equity must also 'do equity'. In this context, this means that if the principal is accepting the benefit of the work done by the fiduciary, there must be some recognition of the fiduciary's effort. As disgorgement of profit is equity's response in cases of fiduciary breach, it may be more fitting to refer to the balance achieved by the granting of an allowance as 'counter-disgorgement'

75 See, eg, Queensland Mines Ltd v Hudson (1978) 18 ALR 1. No breach of fiduciary duty was found here, but the Court commented that, if there had been, a substantial allowance would have been made.

76 See Queensland Mines Ltd v Hudson (No 1) [1976] CCH ACLC 40-266, cited in Robert Deutsch, 'Directors as Fiduciaries: Queensland Mines Ltd v Hudson \& Ors' (1979) 8(3) Sydney Law Review 668, 669. Note that the decision of the trial judge was overturned on appeal as the Privy Council found that no fiduciary duty was owed. See also Boardman v Phipps [1967] 2 AC 46.

77 Warman International Ltd v Dwyer (1995) 182 CLR 544.

78 Ibid 561 [33] (Mason CJ, Brennan, Deane, Dawson and Gaudron JJ).

79 See Harding, above n 63, 356: a 'desert' approach.

80 Smith, above n 50, ch 9. 
rather than 'counter-restitution' ${ }^{81}$ The situation from the breaching fiduciary's perspective is most accurately described by Tipping J:

It would be quite wrong and inequitable...if they were required to account for the gross profit without any deduction and also wrong if they were not allowed some reasonable recompense for their efforts, their skill and the risks which they undertook. It is truly a case where he who seeks equity...must do equity, ie recognise that the profits to which it is prima facie entitled are something in the nature of a windfall. ${ }^{82}$

\section{CONCLUSION}

Fiduciary duties are unique duties of loyalty. However, it is impossible to escape the reality that allowances for breaching fiduciaries have been, and will continue to be, made. If the granting of allowances is based on avoiding the unjust enrichment of the principal (as Australian courts have suggested) ${ }^{83}$ then it is worth exploring the possibility of relying on quantum meruit. The practical application of quantum meruit to breaching fiduciaries has the potential to provide courts with a more concrete basis for quantifying the reasonable remuneration which constitutes the fiduciary's allowance. In theory, it is similar to the claim by a breaching party to the contract; the party has done wrong but has nevertheless expended time, money and effort to attain some kind of benefit for the 'innocent' party. In the case of contract, the breaching party pursues a claim in unjust enrichment. In the case of fiduciary breach, the breaching fiduciary seeks an allowance. ${ }^{84}$ However, quantum meruit applies in both instances to ensure that the breaching party is remunerated fairly to avoid the unjust enrichment of the 'innocent' party/principal independently of the contractual/fiduciary duties owed. This means that, when assessing allowances for breaching fiduciaries, courts can borrow from the established quantum meruit principles in contract law to create a consistent remedial measure in this area of fiduciary law.

81 I am grateful to Professor Charles Rickett for suggesting the use of the term 'counterdisgorgement'.

$82 \quad$ Estate Realties $v$ Wignall [1992] 2 NZLR 615, 630 (Tipping J).

83 Warman International v Dwyer (1995) 182 CLR 544 [33] (Mason CJ, Brennan, Deane, Dawson and Gaudron JJ).

84 It is unclear whether the basis for this is an independent claim or a defence to control remoteness of gain by the principal. 